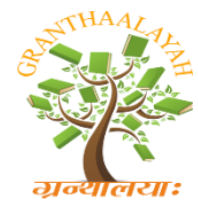

INTERNATIONAL JOURNAL OF RESEARCH GRANTHAALAYAH A knowledge Repository

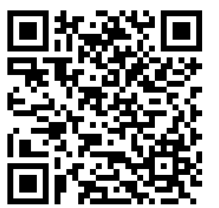

Management

\title{
CONSEQUENCES OF RELATIONSHIP MARKETING ON CUSTOMER LOYALTY
}

\author{
Muhammad Shaukat Malik ${ }^{* 1}$, Huma Ali ${ }^{2}$, Tahir Ibraheem $^{3}$ \\ *1,2,3 Institute of Banking and Finance, Bahauddin Zakariya University (Multan) Pakistan
}

DOI: https://doi.org/10.29121/granthaalayah.v5.i2.2017.1722

\begin{abstract}
The objective of present study is to investigate the consequences of relationship marketing on customer loyalty. The study also investigates the moderating role of customer expertise between relationship marketing and customer loyalty. The data used in the present study was collected by using a self - administered questionnaire. Data were collected from telecom industry of Pakistan; more specifically data source is the telecom users in Multan. Sample size is 500 and these questionnaires were distributed to collect data among top universities located in Multan. Out of 400 received questionnaires 330 were selected for analysis. SPSS (version 20.0) was used for analysis and statistical tools like ANOVA, correlation analysis and multiple regressions were used. The result of the present study show that there exists a direct relation between relationship marketing and customer loyalty as well as customer expertise moderates the relationship.

Keywords: Relationship Marketing; Customer Loyalty; Customer Expertise; Telecom Sector.

CITE THIS ARTICLE: Muhammad Shaukat Malik, Huma Ali, and Tahir Ibraheem (2017). "CONSEQUENCES OF RELATIONSHIP MARKETING ON CUSTOMER LOYALTY." International Journal of Research - Granthaalayah, 5(2), 180-190. https://doi.org/10.29121/granthaalayah.v5.i2.2017.1722.
\end{abstract}

\section{Introduction}

In today's business environment having monopoly is like a luxury thing, organizations ever dream of while the bitter reality is fierce competition which engulfs such organizations which are unable to meet customers' needs and demands and this result in losing loyal customers base. The question arises here for marketers how to gain loyalty of customers and how to retain those loyal customers for a long term. The most feasible solution used by marketers to address this problem is relationship marketing. As explained by Volkov (2004), relationship marketing is a useful technique to understand the customer's needs and demands. According to researchers if an organization seeks to remain competitive in today's competitive environment, using its relationship with customers to its maximum extent, both internally and externally, is the need of time. 
The term relationship marketing has been explained by many researchers aimed to explain this terminology in their own ways. Berry (1983) referred the relationship marketing as a tool of "tempting, developing and increasing relationship with customers". Another study conducted by Groonos (1997) explains the relationship marketing as a strategy of "attaining all the business objectives of both parties through a mutual consent, while generating, developing, enhancing and closing off the relationship at the right time". While Morgan and Hunt, (1994) described the relationship marketing as a" set of activities with the aim of generating benefit for both parties through the process of identifying, maintaining and enhancing healthy relationships". Sheth and Parvatiyar (2000) defined the terminology of relationship marketing as a "Setup of activities and programmers which ensures the benefits for customers and stakeholder through creating, developing and sustaining healthy relationships". According to Demadarige and Valor, (2007) for the organizations to survive in mature markets it's necessarily important to build long term relationship with customers, because having a loyal customers base is the need of time. As described by Ndubisi, Malhotrah and Wah,(2009) that the cost of attracting, engaging and sustaining the new customers is five to six times higher than retaining loyal customers. Researchers also explain the reasons behind these phenomena, i.e. loyal customers are very less prices sensitive as compared to the new ones, and also the switching behavior is very less likely to be occurred in loyal customers.

$\mathrm{Li}$ (2012) defines the term loyalty as an "Instrument which generates long lasting benefits for both parties in relationship". According to many researchers, customer loyalty is the key to gain the competitive advantage as well as it ensures the growth of an organization in long run. Because loyal customers are very difficult to switch as well as they are very less likely to be price sensitive while showing a repetitive purchasing which generates profit for organization. According to Lee and Cunnigaham, (2004) the loyalty of customers can be defined on the basis of their previous purchasing behavior and their future buying commitments with respect to a specific organization. Reiheld and Detrick (2003) defined the loyalty as a "procedure of generating mutual benefits both for the customers and organization on a long-term basis".

According to researcher's customers can show their loyalty with organizations in many different ways, such as by not switching to competitor's products or services even if those are better, or by spreading positive word of mouth regarding organization's products or services or by showcasing an increased buying behavior, But in order to gain such loyalty organizations needs to build trust with its customers. Researchers explained the loyalty as a technique of developing, sustaining and enhancing trusted relationship which channelized the customers to show repetitive purchasing behavior.

Gaining customer loyalty through the usage of effective relationship marketing has become the need of time, that's why many industries are now seeking new ways of gaining customer loyalty as a means of competitive advantage through relations. Telecom industry is one if those sectors where gaining customer loyalty through effective relations handling is the need of time, because in last few decades' telecom sector has made a rapid growth which changes its role in world economy from minor to major. According to Groonos, (2004) this enhancement in telecom sector has changed the face of world economy as the total revenue generated from this sector was 1.2 trillion. 
The sudden growth of telecom sector not only changes the route of world's economy but it also has its impact on individual countries e.g. Pakistan's telecom sector chose to change its position from minor to major key player, by adding more foreign investors, lowering the taxes and by providing subsidies. According to Valdecants (2009) the transition of Pakistan's Telecom sector from minor to major is at its peak this growth not only creates the opportunities for investors but also tempt the researchers to dig this area further more. According to Ali et al, (2010) in order to gain larger market share and create customer loyalty in mature markets like Pakistan's telecom sector effective marketing and long term relations are very much needed.

\section{Problem Discussion}

In today's competitive environment, where consumers are attracted through multiple platforms, i.e. TVC advertisement, radio and newspaper advertisement, direct marketing, telemarketing and aggressive selling, the phenomena of customer's switching is very common. According to Peng and Wang, (2006) relationship marketing is the only tool which can control switching phenomena by generating loyalty of customers with organization.

\section{Literature Review}

\subsection{Review of Relationship Marketing}

In late 90's many researchers think relation based marketing only shows a slight change from marketing as it converted the transaction based marketing with relation based marketing (Gronoos 1994; Sheith \& Parvatiyar 2000; Ahmed et al., 1999; Ballantyne et al., 2003; Brodie et al., 1997).

However, with the beginning of 20th century, relationship marketing has gained a lot of acknowledgement both from researchers and marketers, because relations based marketing emerges as the most dominated technique to gain customer loyalty (Egan,2001; Bradford et al.2010; Murphy and Wang, 2006; Palmatier, 2008; Sharma and Patterson, 2000). According to Peng and Wang, (2006) relationship marketing is an important tool to transform different target groups into loyal customers through generating, developing and sustaining long lasting relationships with customers.

A number of studies have been conducted by the researchers (Sin et al., 2002; Sorce, 2002; Terawatanavong and Quazi, 2006; Vargo, 2009; Veloutsou et al., 2002; Wilkinson and Louise Young, 2002) in order to examine the influence of relationship marketing on customer loyalty. As explained by Buttle (2009), customers based relationship marketing is an essential business technique which summarizes both internal and external functions and processes which is helpful in creating and developing value added service/Products for targeted customers at profit. Another research conducted by Jamil et al. (2012) explains that the primarily focus of relation based marketing strategies is to create loyalty among customers and build strong long term relations with customers. Relationship marketing also aids marketers to differentiate themselves from competitors. Another research was to evaluate the role of relationship marketing for developing and retaining customer loyalty conducted by (Dushyenthan, 2012). Researcher used seven dimensions of relationship marketing i.e. commitment, trust, and quality of employees, 
complaint handling, familiarity and personalization of services. Results of study show that trust and commitment plays the most significant role in gaining the loyalty of customers. A number of researchers display in their studies that relationship marketing is the ultimate tool to gain loyalty of customers, which ensures the growth of organization in long run (Velampy and Sivesan,2012; O'Malle \& Tynan, 2000)

\subsection{Review of Customer Loyalty}

According to Curtis (2009), for the last few decades' loyalty has become one of the major parts of marketing literature. As the loyal customers generate more profit for organizations on long term basis, thus increasing the competitiveness of organization as well as decreasing the cost (Ganesan and Hess, 1997). Addition to this, Fornell and Wernefelt, (1987) explain in their research that the cost of sustaining old customers is much lesser than tempting the new ones, results of their study displays that retaining loyal customers is more crucial for organizations as they are more beneficial in long run.

According to (Morgan et.al. 2004; Moroman et.al. 1992) loyalty is a desire to identify, develop and sustain profitable and important relationships. Rewley and Dawer (1999) explained in their research that loyal customers are generally less sensitive to prices and they are even willing to purchase higher prices. Loyal customers are often more optimistic when the things go wrong. Result of study exhibits that cost incurred on the retention of loyal customers is much cheaper than tempting the new ones.

According to Azam et al. (2013) loyalty is a tool which creates mutual benefits for organization and customers. Waheed et al. (2010) conducted their research to examine the factors which influences the loyalty of customers in Pakistan's telecom sector. Study results show that influence of product image, trust worthiness, and satisfaction on customer's loyalty is significant.

Customer Loyalty has many factors and these factors could have a different effect with respect to different markets. Another study conducted by Sabir et al. (2003) in Pakistan's telecom sector where 18 major determinants were examined that influence the customer loyalty. The results of study display that service quality, price, customer care, promotion, trust, corporate brand image, value added services and promotion play a significant role in developing the loyalty of customers.

According to researchers through effective relationship building benefits can be attained by both parties. Thus, an efficient customer based relation building marketing technique can help the marketers to generate, sustain and enhance firm's profitability and turns the customers into loyal ones.

\subsection{Consequences of Relationship Marketing on Customer Loyalty}

According to Peng and Wang, (2006) relationship marketing aid the marketers to enhance the loyalty of customers as well as it engages the customers on long term basis by providing necessary information which matches their interest and needs. The results of good relation building are often turns to be repetitive purchasing behavior and positive word of mouth. Buttle (2009) describes the influence of effective relation based marketing strategy on customer loyalty, 
"As the core strategy of any business which amalgamates both internal and external process and functions to generate and deliver value to targeted customers at a profit.

Another study was conducted by Hau and Ngo, (2011) in Vietnam to evaluate the influence of relationship marketing on customer loyalty. Results show that trust, shared values, bonding and reciprocity have positive and strong impact on customer loyalty. Webb et al. (2011) identify in their study that the primary goal of relation based marketing is to enhance the satisfaction of customers which ultimately leads to gaining the loyalty of customers.

\subsection{Customer Expertise as Moderator}

Customer Expertise shows the past cognitive experiences of customers with respect to purchasing. A number of studies has been conducted which show that customer experience management is an important technique to generate satisfaction and build long lasting relations with organization (Chen et.al. 2011; Iyiola and Ibidummni, 2013). Another research was conducted by Songsak Wijaithamarith and Teera Taechanebeesti, (2012) in Thailand supermarket in order to examine the effect of customer experience management which influences the loyalty to some extent i.e. repeat purchased, positive word of mouth and up buying. Study result also shows that customer experiences are directly related to satisfaction. If customer experience is good, it will generate more satisfaction which generally leads to customer loyalty. However, if the customer experience turns out to be the bad one, customer experience anger, grief and dissatisfaction regarding organization's product, this often leads to damaging the consumer firm relationship.

\subsection{Conclusion of Literature Indicating Research Gap}

Undeniably, a number of researches have been conduct to unveil the causes of customer loyalty (Morgan et al 2004; Moorman et al 2005). Numerous researchers used customer satisfaction as cornerstone to attain the loyalty (Kishada \& Wahab, 2013; Fornell and Wernerfelt 1987). In previous studies, relationship between relationship marketing and customer loyalty has been determined but in different fashion. However, none of the study has tested these relationships in such integrated fashion as have been proposed in the present study while applying the moderating role of customer expertise.

\section{Conceptual Model and Hypothesis}

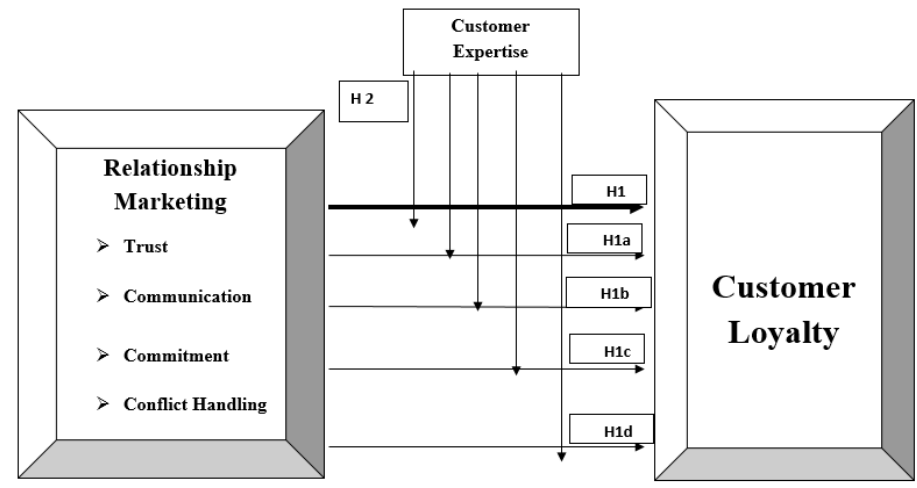

Figure1: Consequences of Relationship Marketing on Customer Loyalty. 


\subsection{Hypothesis Development}

H1 = Relationship based marketing affects the customer loyalty.

$\mathrm{H} 1 \mathrm{a}=$ Trust significantly affects the customer loyalty.

$\mathrm{H} 1 \mathrm{~b}=$ Communication affects the customer loyalty.

$\mathrm{H} 1 \mathrm{c}=$ Conflict handling affects the customer loyalty.

$\mathrm{H} 1 \mathrm{~d}=$ Commitment affects the customer loyalty.

$\mathrm{H} 2$ = Customer expertise moderates the relationship of relationship marketing and customer loyalty.

$\mathrm{H} 2 \mathrm{a}=$ Customer expertise moderates the relationship of Trust and customer loyalty.

$\mathrm{H} 2 \mathrm{~b}=$ Customer expertise moderates the relationship of Communication and customer loyalty.

$\mathrm{H} 2 \mathrm{c}=$ Customer expertise moderates the relationship of Conflict handling and customer loyalty.

$\mathrm{H} 2 \mathrm{~d}=$ Customer expertise moderates the relationship of Commitment and customer loyalty.

\section{Research Methodology}

According to Aaker et al. (2001) research design is a tool which gives instructions to conduct a research. As explained by Green and Kriger, (1987) in their research that an accurate research designs aids in generating relevant and suitable data. Therefore, research design used to separate unrelated data that has no relativity with research topic.

As Suggest by Sounder et al. (2000), there are three types of researches based on their objective; Explanatory, descriptive and exploratory. The objective of this research is to test the hypothesis, therefore explanatory method of research will be used as its shows the cause and effect relationship.

\subsection{Population and Sample Description}

For the present study data were collected from telecom industry of Pakistan, more precisely data were collected from telecom users in Multan. All the telecom users in Multan summarize the population but in order to get data more accurately and conveniently university were taken as a sample. 500 questionnaires were given to the students of universities and campuses of universities i.e. National University of Modern Languages, Bahauddin Zakriya University and University of Education. Out of 500 questionnaires 400 were returned from which 330 questionnaires were selected as they are properly and completely filled.

\subsection{Regression Analysis}

Regression analysis is used to build an equation which can predict the results of dependent variables when one or more independent variables were applied. Below equation shows the regression analysis form

$\mathrm{Y}=\mathrm{b} 1 \mathrm{X} 1+\mathrm{b} 2 \mathrm{X} 2+\ldots+\mathrm{A}$ 
Table 1: Regression Analysis for relationship

\begin{tabular}{|l|l|l|l|l|}
\hline Predictor & R2 & F & Beta & Sig. \\
\hline Relationship & .368 & 191.120 & .607 & .000 \\
Marketing & & & & \\
Trust & .210 & 86.980 & .458 & .000 \\
Communication & .150 & 57.751 & .387 & .000 \\
Conflict & .055 & 19.273 & .236 & .000 \\
Handling & & 169.750 & .584 & .000 \\
Commitment & .341 & & & \\
\hline
\end{tabular}

$\mathrm{DV}=$ Customer Loyalty, at $\mathrm{p}<.05$

Table 1 shows that regression analysis, which shows that the $\mathrm{R}$ square values of Relationship marketing (.368), Trust (.210), Communication (.150), Conflict Handling (.055) and Commitment (.341) revealing that all the factors of relationship marketing has a positive and significant influence on customer loyalty.

The results of study approved our first hypothesis $\mathrm{H} 1$ (H1a, H1b, H1c, H1d) that effective relationship based marketing can influence the loyalty of customers. According to Michael Volker, (2004) in today's competitive environment organizations needs to develop effective relationship based strategies through which they can understand the need and complaints of consumer and by fulfilling those needs and complaints they can earn the loyalty of customers.

\subsection{Moderation}

Moderation is a process which explains how causal relationship between two variables is affected by the third variable termed as moderation (Cooper, Russell, \& Frone, 1990).

$\mathbf{Y}=\boldsymbol{\alpha}+\mathbf{a X 1}+\mathbf{b X 2}+\mathbf{e 0}$

Table 2: Moderation Analysis

\begin{tabular}{|l|l|l|l|l|}
\hline Predictor & R2 & F & Beta & Sig. \\
\hline Relationship & .376 & 98.417 & .571 & .000 \\
Marketing & & & & \\
Trust & .242 & 52.267 & .401 & .000 \\
Communication & .206 & 42.349 & .338 & .000 \\
Conflict & .131 & 24.624 & .190 & .000 \\
Handling & & & .543 & .000 \\
Commitment & .352 & 88.791 & & \\
\hline
\end{tabular}

DV $=$ Customer Loyalty, at $\mathrm{p}<.05$

Table 2 shows the moderation effect, the increased values of $\mathrm{R}$ square of Relationship marketing (.376), Trust (.242), Communication (.206), Conflict Handling (.131) and Commitment (.352) revealing that all the factors of relationship marketing has a positive and significant influence on customer loyalty and with the effect of moderator customer expertise on this relation the influence of relationship marketing on customer loyalty is further increased. 
These values exhibit that relationship based marketing notably effects the customer loyalty even further more when customer expertise act as a moderator in this relation.

Above test results support our hypothesis $\mathrm{H} 2(\mathrm{H} 2 \mathrm{a}, \mathrm{H} 2 \mathrm{~b}, \mathrm{H} 2 \mathrm{c}, \mathrm{H} 2 \mathrm{~d})$ that customer expertise act as a moderating variable between relationship marketing and customer loyalty. Previous researches also support our finding; according to Chen et al. (2011) customer expertise enhances the relation strength of relationship marketing and customer loyalty.

\section{Conclusion}

It is concluded that components of relationship marketing increase the loyalty of customer. And the strength of relationship enhanced by taking customer expertise as a moderator. Study results also displays that out of four factors of relationship based marketing commitment contains the strongest impact at the loyalty of customer, while trust, communication and conflict handling comes second, third and fourth respectively. Results of this study explains that commitment is the most important factor as it encourages the customers to overcome uncertainty and build healthy strong relationship with organizations which ultimately lead to customer loyalty. According to researchers in service providing sector specifically telecom sector, commitment plays the key role because of its influence on intention to continue and increase mutual benefits both for organization and customer. Due to this, the telecom firms should first show high commitment towards its customers, and results of this will create customer loyalty that eventually leads to building strong, stable, long-term relationships.

\subsection{Practical Implication}

Study results are significantly important for marketers as it helps in understanding the benefits of having good relations with customers. The outcomes of this study give motivation to companies and marketers to build effective relation based marketing strategies while keeping in mind the needs and demands of customer side. Solving complaints and minimizing conflicts on priorities bases can help in building customers trust and they become more loyal towards company. Therefore, it is important for telecom sector marketers to develop relationship marketing programs at ongoing bases with existing customers and turned them into loyal ones in order to gain the market share and growth.

\subsection{Future Research}

For the study at hand sample was taken only from one city of Pakistan that is "Multan", due to limited resources. Future research can be done taking multiple cities into account. Secondly future researcher can also use more moderators to examine the impact of relationship marketing on customer loyalty.

\section{References}

[1] Abdullah, F., \& Kanyan, A. (2013). Managing the Dimensions of Relationship Marketing in the Food Service Industry. Jurnal Pengurusan 37, 91-103 
[2] Ahmed, F., Patterson, P. and Styles, C. (1999), "The determinants of successful relationships in international business", Australasian Marketing Journal, Vol. 7 No. 1, pp. 5-21

[3] Akhter, W., Abbasi, A. S., Ali, I., \& Afzal, H. (2011). Factors affecting customer loyalty in Pakistan. African Journal of Business Management Vol. 5(4) , 1167-1174

[4] Ali, J. F., Rehman, K. u., Yilmaz, A. K., \& Afzal, N. S. (2010). Determinants of consumer retention in cellular industry of Pakistan. African Journal of Business Management Vol. 4(12), 2402-2408

[5] Ballantyne, D., Christopher, M. and Payne, A. (2003), "Relationship marketing: looking back, looking forward”, Marketing Theory, Vol. 3 No. 1, pp. 159-66

[6] Berry, Leonard L (1983). 'Relationship marketing' in Emerging perspectives on services marketing, L. Berry, G L Shostack and G D Upah, eds.: American Marketing Association, Chicago, 25-28.

[7] Bradford, K., Brown, S., Ganesan, S., Hunter, G., Onyemah, V., Palmatier, R., Rouzies, D., Spiro, R., Sujan, H. and Weitz, B. (2010), "The embedded sales forces: connecting buying and selling organizations", Marketing Letter, Vol. 21, pp. 239-53.

[8] Brodie, R.J., Coviello, N.E., Brookes, R.W. and Little, V. (1997),“Toward a paradigm shift? An examination of contemporary marketing practices",Journal of Marketing Management, Vol. 13 No. 5, pp. 383-406.

[9] Bojeia, J., Radam, A., \& Abu, M. L. (2012). the underlying dimensions of relationship marketing in the malaysian mobile service sector. 3rd international conference on business and economic research ( 3rd icber 2012 ) proceeding, (pp. 972-991). Indonesia.

[10] Buttle, F., 2009. Customer Relationship Management: Concepts and Technologies. 2nd ed. Amsterdam: Elsevier

[11] De Madariaga, J. G., \& Valor, C. (2007). Stake-holders management system: empirical insights from relationship marketing and market orientation perspective. Journal of Business Ethics, 71(4), 425-439

[12] Dushyenthan, M. T. (2012). interactive marketing and its impact on customer satisfaction- The study of mobile communication service providers in Jaffan Sir-Lanka ( A Comparitive study of Dialog and Mobitel). Global Journal of Management and Business research , 56-66.

[13] Egan, J. (2001). Relationship Marketing: Exploring Relational Strategies in Marketing, Pearson Education Limited, ISBN 0273-64612-5

[14] Grönroos, Christian (1994), "From Marketing Mix to Relationship Marketing: Towards a Paradigm Shift in Marketing."'Management Decision 32 (2),4-20

[15] Claes, Fornell \& Birger, Wernerfelt. (1987). Defensive marketing strategy by customer complaint management: A theoretical analysis.Journal of Marketing Research, 24, 337-346

[16] Cooper, M. L., Russell, M., \& Frone, M. R. (1990). Work stress and alcohol effects: A test of stress-induced drinking. Journal of Health and Social Behavior, 31, 260-276.

[17] Curtis, A.(Year). Source-receiver seismic interferometry. SEG Technical Program Expanded Abstracts 2009. 3655-3659.

[18] Ganesan, S. and Hess, R. (1997) Dimensions and levels of trust: implications for commitment to a relationship. Marketing letters 8 (4), 439-448.

[19] Grönroos, Christian (1997), "Value-Driven Relational Marketing: From Products to Resources and Competencies." Journal of Marketing Management 13 (4), 407-19. 
[20] Gronroos, C. (2004). The relationship marketing process: Communication, interaction, dialogue, value. Journal of Business and Industrial Marketing, 19(2), 99-113

[21] Haghkhah, A., Hamid, A. B., Ebrahimpour, A., Roghanian, P., \& Gheysari, H. (2013). Commitment and Customer Loyalty in Business-To-Business Context. European Journal of Business and Management, 156-165

[22] Hau, L. N., \& Ngo, L. V. (2012). Relationship marketing in Vietnam: an empirical study. Asia Pacific Journal of Marketing and Logistics , 224-235. (37)

[23] Lee, M., \& Cunningham, L. F. (2001). A cost/benefit approach to understanding service loyalty. Journal of Services Marketing, 15(2), 113-130

[24] Li, M. 2009. The Customer Value Strategy in the Competitiveness of Companies. International Journal of Business and Management, 4(2): 136-142 (49)

[25] O'Malle, L., \& Tynan, C. (2000). Relationship marketing in consumer markets Rhetoric or reality? European Journal of Marketing Volume 4 No.7 , 797-815.

[26] Mohr, C. D., Armeli, S., Tennen, H., Temple, M., Todd, M., Clark, J., \& Carney, M. A. (2005). Moving beyond the keg party: A daily process study of college student drinking motivations. Psychology of Addictive Behaviors, 19, 392-403

[27] Moorman, Christine, Gerald Zaltman, and Rohit Deshpandé (1992), "Relationships between Providers and Users of Market Research: The Dynamics of Trust within and Between Organizations.” Journal of Marketing Research 29 (August), 314-29

[28] Morgan, Robert M., and Shelby D. Hunt (1994), "The Commitment-Trust Theory of Relationship Marketing." Journal of Marketing 58 (July), 20-38

[29] Murphy, B. and Wang, R. (2006),“An evaluation of stakeholder relationship marketing in China”, Asia Pacific Journal of Marketing and Logistics, Vol. 18 No. 1, pp. 7-18.

[30] Ndubisi, N. O. (2007). Relationship Marketing and Customer loyalty. Marketing Intelligence \& Planning , 98-106

[31] Ndubisi, N. O., Malhotra, N. K., Wah, C. K., 2009. Relationship marketing, customer satisfaction and loyalty: A theoretical and empirical analysis from an Asian perspective. Journal of International Consumer Marketing 21(1), 5-16

[32] Palmatier, R.W. (2008), "Interfirm relational drivers of customer value", Journal of Marketing Vol. 72, pp. 76-89

[33] Peng, L.Y. and Q. Wang, 2006. Impact of relationship marketing tactics (RMTs) on switchers and Stayers in a competitive service industry. J. Marketing Manag., 22: 25

[34] Rowley, J., \& Dawes, F. (1999). Customer loyalty- a relevant concept for Libraries? Library Management- Volume 20 , 345-351

[35] Reichheld, F., \& Detrick, C. (2003). Loyalty: A prescription for cutting costs. Marketing Management, 12(5), 24-25

[36] Sabir, R. I., Irfan, M., Irfan, M., Sarwar, B., \& Sarwar, B. (2013). The Impact of Service Quality, Customer Satisfaction and Loyalty Programs on Customer's Loyalty: An Evidence from Telecommunication Sector. Journal of Asian Business Strategy , 306-314

[37] Sin, L., Tse, A., Yau, O., Lee, J. and Chow, R. (2002), “The effect of relationship marketing orientation on business performance in a service-oriented economy", Journal of Services Marketing, Vol. 16 No. 7, pp. 656-76 
[38] Sharma, N. and Patterson, P. (2000), "Switching costs, alternative attractiveness and experience as moderators of relationship commitment in professional, consumer services",International Journal of Service Industry Management, Vol. 11 No. 5, pp. 470-90.

[39] Sheith, Jagdish N., and Atul Parvatiyar (1999), the domain and conceptual foundations of relationship marketing. Thousands Oaks, Calif.: Sage Publications, Inc

[40] Sorce, P. (2002), Relationship Marketing Strategy, Printing Industry Center, Rochester Institute of Technology, Rochester, NY

[41] Terawatanavong, C. and Quazi, A. (2006), "Conceptualising the link between national cultural dimensions and B2B relationships", Asia Pacific Journal of Marketing and Logistics, Vol. 18 No. 3, pp. 173-83

[42] Valdecantos, C. (2009), Online available at http://consultantvalueadded.com/2009/01/12/emergin gmarkets-telecom-market-review pakistan-2008/

[43] Vargo, S.L. (2009), "Toward a transcending conceptualization of relationship: a service-dominant logic perspective", Journal of Business \& Industrial Marketing, Vol. 24 Nos 5/6, pp. 373-9.

[44] Velnampy, T., \& Sivesan, S. (2012). Impact of customer relationship marketing on customer value creation in mobile service providers - a Sri Lankan experience. Herald Journal of Marketing and Business Management Vol. 1 (1) , pp. 016 - 021

[45] Veloutsou, C., Saren, M. and Tzokas, N. (2002), "Relationship marketing: what if?"European Journal of Marketing, Vol. 36 No. 4, pp. 433-49

[46] Volkov, M. (2004). Successful Relationship Marketing: Understanding the Importance of Complaints in a Consumer-Oriented Paradigm. Problems and Perspectives in Management , 113123.

[47] Webb, D., Webster, C. and Krepapa, A. (2011), An exploration of the meaning and outcomes of a customer-denied market orientation ${ }^{\circ}$, Journal of Business Research, Vol. 48, pp. 101-12

[48] Wilkinson, I. and Louise Young, L. (2002), "On cooperating: firms, relations and networks", Journal of Business Research, Vol. 55 No. 2, pp. 123-32

[49] Yohai V. J. (1987), "High Breakdown Point and High Efficiency Robust Estimates for Regression," Annals of Statistics, 15, 642-656.

*Corresponding author.

E-mail address: tahir.ibrahim16@outlook.com 